\title{
Emancipation Day Celebrations: The Commemoration of Slavery and Freedom in Iowa
}

\author{
LESLIE A. SCHWALM
}

IN 1898 JOHN'L. THOMPSON, editor of the Iowa State Bystander, Iowa's most prominent black newspaper, gave the keynote address at Keokuk's Emancipation Day celebration. He asked his audience to meditate on the history and the experience of slavery:

Think of being compelled to live all your life with the man who is stealing the babies from your cradle and you dare not say one word; think of being compelled to associate with the despised and hated southerner who is constantly robbing you; think of being compelled to separate from your dear brother, loving sister, only father and mother, never to see them again. The agonizing groans of mothers when separated from their crying children were heart piercing. See the slave scarred veterans who are before me today and have witness to their once cruel and inhuman treatment. For 243 years the slave pen, the auction block and the whipping post were all perpetuated within the sunny south; for 243 years the blood hound was raised to trace women through tangled swamps and craggy mountains. . . Four million souls in fetters; $4,000,000$ bodies in chains; all the sacred relations of wife, fathers and mothers trampled beneath the brutal feet of avarice and might, and yet, fellow citizens, all of this was done under our beautiful and socalled flag of the free.

The research for this article was supported by the State Historical Society of Iowa, the University of Iowa, and the National Endowment for the Humanities.

THE ANNALS OF IOWA 62 (Summer 2003). (C) The State Historical Society of Iowa, 2003. 
Thirty-five years had passed since the Emancipation Proclamation. During that time black Iowans-former slaves and the children of slaves-had struggled to shape the collective memory of bondage, war, and freedom. Thompson's address, with its vivid and devastating images of life under slavery and its charges of national hypocrisy, came at a turning point in the way black Iowans commemorated slavery and emancipation. His Emancipation Day invocation of the collective memory of slavery's brutality was becoming increasingly rare; in the 1890s, Iowa's Emancipation Day celebrations more often focused on the progress that had occurred since the end of slavery.

This local change over the content and uses of history echoed a larger national debate over how Americans should remember slavery and the Civil War. Had the war been an honorable fight over states' rights or a divinely ordained war against slavery? Had slavery been brutal and immoral, or had it been a time of racial harmony and civilizing influence over people of African descent? Across the country, African Americans debated among themselves the uses of the history of slavery: was it a reminder of a shameful past, best forgotten, or was the past a valuable resource for contemporary black life and culture?

By the 1890s, the answers to these questions came from several different quarters, such as the white writers who romanticized the history of slavery in the "plantation school" of American literature, substituting a sentimental trope of antebellum

I would like to thank the Annals of Iowa's reviewers, as well as Kathleen Diffley, Kim Marra, and Laura Rigal, for their astute and helpful comments. I benefited, as well, from the superb research assistance of Kellie Carter, Patricia Reid, Jennifer Harbour, Eric Lana, John Zeller, Kate Stewart, Kate Donovan, Becky Pulju, Crystal, Lewis-Colman, and Lee Attenburg, as well as the expertise and encyclopedic knowledge of Mary Bennett.

1. Newspaper clipping, 8/4/1898, "Ethnicity-Negro" folder, vertical file, Keokuk Public Library. Thompson's mother, Mary Anne Shepard, was born into slavery in Missouri. Her widowed mother brought her and three siblings to Ringgold County, Iowa, during the Civil War, moving to Decatur City and then to Des Moines by 1866. See her obituary, Iowa State Bystander, 11/20/1903. Thompson edited the Bystander from 1896 until 1919. He earned his law degree in 1898 , was the only African American to pass the state bar exam that year, and was the second black lowan admitted to practice law in federal courts. Allen W. Jones, "Equal Rights to All, Special Privileges to None: The Black Press in Iowa, 1882-1985," in The Black Press in the Middle West, 1865-1985, ed. Henry Lewis Suggs (Westport, CT, 1996), 77. 
interracial kindness and mutual devotion for the reality of slavery's violence and exploitation. The answers were also offered by the increasingly popular collective memory of the war, created by northern and southern whites alike, which erased black participation and what historian David Blight has described as the "emancipationist legacy" of the war. And, at the same time, many African Americans offered their own answers, as they sought to distance themselves from the memory of slavery and the contagion of victimization and inferiority that many thought it seemed to carry, particularly as racist violence and the abrogation of African American civil rights in the South threatened to undermine the achievements of the post-emancipation generation. Thompson's stirring speech suggests that Iowa, like the rest of the nation, was deeply engaged in the question of whether, and how, to remember and memorialize American slavery and the war that brought it to an end. Thus his speech opens a window into the local history of this debate and in particular its consequences for black Iowans. ${ }^{2}$

In the proliferation of emancipation celebrations following the Civil War, black Iowans created a cultural form that drew

2. Literary scholar Henry Louis Gates Jr., writing in the New York Times, $2 / 9 / 2003$, has argued that at the turn of the century "slavery had become something of an embarrassment to an aspiring black elite desperate to integrate into a gilded American age." A large body of scholarship by historiansas well as literary scholarship on black autobiography and slave narrativeshas addressed the meaning of the history of slavery. See David Blight's masterful survey, Race and Reunion: The Civil War in American Memory (Cambridge, MA, 2001), 216-31, 284-91; idem, Beyond the Battlefield: Race, Memory, and the American Civil War (Amherst, MA, 2002), 120-52; Kirk Savage, Standing Soldiers, Kneeling Slaves: Race, War, and Monument in Nineteenth-Century America (Princeton, 1997), 89-128; and Michael Kammen, Mystic Chords of Memory: The Transformation of Tradition in American Culture (New York, 1991), 122. See also William L. Andrews, "Reunion in the Postbellum Slave Narrative: Frederick Douglass and Elizabeth Keckley," Black American Literature Forum 23 (1989), 516, and his essays, "The Representation of Slavery" and "Toward a Poetics of Afro-American Autobiography," in Afro-American Literary Study in the 1990s, ed. Houston A. Baker Jr. and Patricia Redmond (Chicago, 1989), 78-104; Frances Smith Foster, Written by Herself: Literary Production by African American Women, 1746-1892 (Bloomington, IN, 1993); Jennifer Fleischner, Mastering Slavery: Memory, Family, and Identity in Women's Slave Narratives (New York, 1996); and Carolyn Sorisio, "Unmasking the Genteel Performer: Elizabeth Keckley's Behind the Scenes and the Politics of Public Wrath," African American Review 34 (2000), 19-28. 
from the more solemn, formal rituals of commemoration (such as prayers, orations, and recitals), the exuberant sociability of festivals (including music, dancing, food, and drinking), the public performance of civic and expressive culture (particularly in parades and processions), and the more private elements of indoor meetings shielded from the white public gaze (including "experience meetings" held in black churches). ${ }^{3}$ Combining performance and participation, politics and protest, the public and the private, as well as the rural and the urban, midwestern emancipation celebrations of the nineteenth and twentieth centuries became an important site for black expressive culture at the same time that they became one of the region's most important venues for articulating the dynamic relationship between history and public memories of slavery, war, and emancipation. ${ }^{4}$

The record of Iowa's Emancipation Day celebrations exists today in the form of newspaper reports in Iowa's white press

3. My understanding of the culture of parades and festivals draws on the important work of Susan G. Davis in Parades and Power: Street Theatre in Nineteenth-Century Philadelphia (Philadelphia, 1986), 1-48; and Kammen, Mystic Chords of Memory.

4. There is an extensive literature on the history of public commemoration among African Americans. Mitch Kachun's Festivals of Freedom: Memory and Meaning in African American Emancipation Celebrations, 1808-1915 (Amherst, $M A, 2003$ ) explores the changing venues and content of emancipation celebrations, offering significant insight into the development of African American historical thinking and the processes by which black collective histories have been shaped, challenged, revised, and commemorated. Genevieve Fabre and Robert O'Meally, eds., History and Memory in African-American Culture (New York, 1994), contains important essays on African American history and memory, including Genevieve Fabre's "African-American Commemorative Celebrations in the Nineteenth Century," 72-91. Also helpful is William B. Gravely, "The Dialectic of Double-Consciousness in Black American Freedom Celebrations, 1808-1865," Journal of Negro History 67 (1982), 302-17; Kathleen Clark, "Celebrating Freedom: Emancipation Day Celebrations and African American Memory in the Early Reconstruction South," in Where These Memories Grow: History, Memory, and Southern Identity, ed. W. Fitzhugh Brundage (Chapel Hill, NC, 2000), 107-32; W. Fitzhugh Brundage, "No Deed But Memory," ibid., 1-28; Shane White, "It Was a Proud Day': African Americans, Festivals, and Parades in the North, 1741-1834," Joumal of American History 81 (1994), 13-50; William H. Wiggins Jr., O Freedom! Afro-American Emancipation Celebrations (Knoxville, TN, 1987); Patrick Rael, Black Identity and Black Protest in the Antebellum North (Chapel Hill, NC, 2002), 54-81; and B. W. Higman, "Remembering Slavery: The Rise, Decline and Revival of Emancipation Day in the English-Speaking Caribbean," Slavery and Abolition 19 (1998), 90-105. 
(which had a wide range of political affiliations and editorial leanings) and, beginning in 1894, in the Iowa State Bystander. The Bystander was the state's most successful black newspaper (it would continue in print until 1986). Published in Des Moines but carrying news from black communities large and small across the state, the Bystander served black Iowans, defended their civil rights, and challenged racism both near and far. ${ }^{5}$ While the white press often resorted to racist caricature in its reporting on the activities of black Iowans, the Bystander, as an advocate of black progress, emphasized the positive, and rarely dwelled on the tensions that sprang from conflicts over class and color within Iowa's black communities. Neither the Bystander nor the white press consistently reported on what we might regard as the total matrix of Emancipation Day commemorations, such as the impact of observers and audience members, as well as participants, on the day's events. Yet the combined record of black and white newspaper reporting provides a rich and substantial record of Emancipation Day activities in the state.

Emancipation Day celebrations, as reported in Iowa newspapers, offer evidence of an expressive culture developed and deployed by African Americans in a persistent effort to shape a collective memory of slavery, war, emancipation, and the fight for citizenship in the century that followed the Emancipation Proclamation. These celebrations point to the uses and meaning of the public sphere in the history of African American community life, and reveal expressive culture as both a social and political practice. ${ }^{6}$ Always multilayered and variously including

5. The Bystander's editors-and its editorial positions-changed over time, becoming more politically conservative in the 1920s and ' 30 s, although the paper would remain community-oriented. With a circulation of 1,750 by 1899 , the Bystander by that time had subscribers in three-fourths of Iowa's counties, in more than half the states of the Union, and in two foreign countries. While white newspapers survived primarily on advertising revenue, black newspapers typically relied on subscriptions, so the paper's success in covering community events across the state was critical to its survival. Jones, "Equal Rights to All," 71-106.

6. See Houston A. Baker Jr., "Critical Memory and the Black Public Sphere," in The Black Public Sphere: A Public Culture Book, ed. The Black Public Sphere Collective (Chicago, 1995), 7-37. The record of Iowa's emancipation celebrations also suggests that the periodization of American public life and ceremonial 
music, speech, food, visual images, costumes, and public mobilization, Emancipation Day celebrations must be viewed as complex cultural performances, each component contributing in unique ways to the total impression left on participants and observers. ${ }^{7}$ The cheers and jeers that met the emergence of a new African American civic culture in city streets and courthouse squares also reminds us that the battlegrounds of citizenship extended beyond the ballot box, and spilled over into a larger public culture.

Emancipation Day celebrations also illuminate the pivotal moment that Thompson's 1898 address marked. While harkening back to an earlier nineteenth-century tradition in which black Iowans acknowledged their slave past when commemorating emancipation, Thompson also represented a later generation's negotiation of a new era in American race relations, an era that brought forth new forms of racism and produced new forms of rhetoric. By the 1890s, the struggle for citizenship would change, and with it the uses and meaning of the history of slavery and emancipation for African Americans in Iowa and across the nation.

civic culture is incomplete without a careful consideration of the public politics of race. Kammen's Mystic Chords of Memory and Mary P. Ryan's Women in Public: Between Banners and Ballots, 1825-1880 (Baltimore, 1990) offer brilliant assessments of change over time in collective memory and the uses of the public sphere, but neither work is guided by the changing politics of race or the impact of race on how history becomes publicly commemorated. I have drawn on the insightful explorations of black vernacular and political culture offered in Shane White, "A Question of Style: Blacks in and around New York City in the Late 18th Century," Joumal of American Folklore 102 (1989), 23-44; Elsa Barkley Brown, "Negotiating and Transforming the Public Sphere: African American Political Life in the Transition from Slavery to Freedom," in The Black Public Sphere, 111-150; Julie Saville, "Rites and Power: Reflections on Slavery, Freedom and Political Ritual," Slavery and Abolition 20 (1999), 81-102; Tera W. Hunter, To 'Joy My Freedom: Southern Black Women's Lives and Labors after the Civil War (Cambridge, MA, 1997); and Robin D. G. Kelley, Race Rebels: Culture, Politics, and the Black Working Class (New York, 1994).

7. Although some scholars emphasize speeches and oration as the most important element of the exercises, the complex assemblage of parades, picnics, banners, and dancing all contributed to the meaning of the celebrations. My approach to understanding this complex performance draws on Susan Davis's exploration of parades as "street theater" in Parades and Power, 13-20. 
BY THE TIME John Thompson gave his address in 1898, Emancipation Day celebrations already had a long history in Iowa. Iowans had begun commemorating emancipation as early as August 1857, when the small but politically active African American community in Muscatine marked the anniversary of the abolition of slavery in the British West Indies on August $1,1834 .^{8}$ The all-day event in this small Mississippi River town involved children and adults and attracted participants from elsewhere in the state. That morning, a public procession began at the African Methodist Episcopal (AME) Church and marched through the city to a local park. There celebrants listened to speeches by local leaders, enjoyed music by the African Brass Band, shared a dinner, and returned in procession to the church for another talk on education. Among the "masterful" speakers who held the audience's attention were Alexander Clark, one of the state's most successful and politically active African Americans, and Rev. Richard H. Cain of the city's AME congregation, best known for his subsequent work as a missionary among South Carolina's freedpeople, as an elected official during Reconstruction, and as bishop of the AME Church in 1880.' The celebration culminated that evening on a distinctly secular note, with a public ball held in a local hall.

8. By 1857, Muscatine's black population (counted at 69 in the 1850 U.S. census) had already assisted in the protection of a fugitive slave, sent a delegate to the National Colored Convention held at Rochester, New York, in 1853, petitioned Iowa's state legislature to repeal the 1851 law limiting black migration into the state, and organized the state's first black convention, which met at Muscatine within days of this emancipation commemoration. See J. P. Walton, "Unwritten History of Bloomington (Now Muscatine) in Early Days," Annals of Iowa 1 (1882), 47-49; Muscatine Journal, 1/27/1888 (typewritten transcription), Alexander Clark file, Musser Public Library, Muscatine; petition \#11, "Petitions, Blacks and Mulattos, Rights of," General Assembly, Secretary of State Papers, State Archives, State Historical Society of Iowa, Des Moines; and Robert R. Dykstra, Bright Radical Star: Black Freedom and White Supremacy on the Hawkeye Frontier (Cambridge, MA, 1993), 151, 154, 173.

9. On Alexander Clark, see Richard, Lord Acton and Patricia Nassif Acton, "A Legal History of African-Americans: From the Iowa Territory to the State Sesquicentennial, 1838-1996," in Outside In: African-American History in Iowa, 18382000, ed. Bill Silag (Des Moines, 2001), 71-73, as well as the collection of materials in the Alexander Clark file, Musser Public Library, Muscatine. On Richard Cain, see Richard R. Wright, Centennial Encyclopedia of the African Methodist Episcopal Church (Philadelphia, 1916), 269. Muscatine was Cain's first charge. 
This earliest recorded emancipation celebration in Iowa was part of a larger calendar of public celebrations northern blacks observed before the Civil War. Many festival days-Pinkster in New York, Negro Election Day and General Training. Day in New England, among others-had eighteenth-century origins and were unrelated to emancipation; in the nineteenth century, however, new holidays and celebrations emerged that commemorated the advent of various state, national, and international inroads against slavery. ${ }^{10}$ The date and meaning of these antislavery celebrations changed over the course of history. The ending of the foreign slave trade in the United States in 1808 and the 1827 legislation ending slavery in New York prompted commemorative holidays in several states, but West Indian emancipation, initiated on August 1, 1834, superceded most of these holidays and helped sharpen the explicit political content of emancipation celebrations. Celebrants typically contrasted Britain's liberation of West Indian slaves with the continued betrayal of enslaved people in the United States, emphasized the hypocrisy of July Fourth celebrations that exalted American liberties, and posited an argument for a future free of slavery and racial inequalities. As scholar Genevieve Fabre has argued, emancipation celebrations reflected a "subjunctive mood," oriented toward what should or ought to be as well as toward the past. $^{11}$

African Americans in the North celebrated and commemorated these antebellum inroads against slavery because slavery continued to influence their lives. Many had themselves been born into slavery, and many more had parents or other family members who had been or were still enslaved. ${ }^{12}$ (Slavery persisted in several northern states well into the antebellum era, a

10. See White, "'It Was a Proud Day'"; and Rael, Black Identity and Black Protest.

11. Fabre, "African American Commemorative Celebrations," 72-73.

12. For example, Charlotta Pyles, a former slave from Kentucky who came to Keokuk after she and most of her family were manumitted, struggled to buy her remaining family members out of slavery. This prompted a trip east in 1855 for a fundraising tour. One of her stops included an Emancipation Day celebration in New York City, where she encountered a sympathetic audience. New York Times, 8/2/1855; Essie M. Britton, "Early Negro Families in Iowa," WPA Project, Ethnicity-Negro folder, vertical file, Keokuk Public Library; Hallie Q. Brown, Homespun Women and Other Women of Distinction (1926), 34-45. 
legacy of gradual emancipation laws. Slaves could also be found among Iowa's black population, even though it was contrary to territorial, state, and federal law. ${ }^{13}$ ) Throughout the Midwest, African American freedom required constant vigilance against the threat of being kidnapped and sold south, against local laws that threatened involuntary servitude for African Americans who became dependent on public support, and against efforts to enforce state laws that restricted or prohibited the in-migration of free blacks. ${ }^{14}$ As long as slavery persisted in the United States,

13. On slaves in territorial and antebellum Iowa, see Leola Nelson Bergmann, "The Negro in Iowa," Iowa Journal of History and Politics 46 (1948), 3-90; John Carl Parish, John Chambers (Iowa City, 1909), 113, 118, 122, 125, 139, 226, 240; Edward H. Stiles, Recollections and Sketches of Notable Lawyers and Public Men of Early lowa (Des Moines, 1916), 10, 14; Herbert M. Hoke, "Negroes in Iowa: Evidence of Negroes Here in the Early Days," 5/7/1940, MsC295, Federal Writers Project, Iowa, University of Iowa Special Collections, Iowa City; George Frazee, "The Iowa Fugitive Slave Case," Annals of Iowa 4 (1899), 118-37; Homer L. Calkin, "A Slave Owner in Iowa," Palimpsest 22 (1941), 344-45; Olive Cole Smith, Mt. Pleasant Recalls Some of the Happenings of Her First Hundred Years (Mount Pleasant, 1942), 15-16; Davenport Gazette, 8/5/1865 (noting a district court suit by a former slave woman held by her owners for uncompensated labor for 13 years while a resident of Iowa); Nathan Isbell Diary, 6/8/1848, State Historical Society of Iowa, Iowa City; History of Johnson County, Iowa (Iowa City, 1883), 463; Iowa State Register, 2/8/1860; Jack Hardin Gillihan, Memoir and Clippings, n.p., Nodaway Valley Museum Underground Railway Binder; and Black History Binder, $\mathrm{BH} 128$, both in Nodaway Valley Museum, Clarinda; Will Porter, Annals of Polk County, Iowa, and City of Des Moines (Des Moines, 1898), 364; Essie M. Britton, "Freedom for the Negroes" and "The Negro in lowa: History of the Colored Race of People Residing in Keokuk and Vicinity," both filed under Ethnicity-Negro folder, vertical file, Keokuk Public Library; George Wilson Jr., "George Wilson: First Territorial Adjutant of the Militia of Iowa," Annals of Iowa 4 (1901), 563-76; Lyons Mirror, 11/26/1857; Iowa Weekly Citizen, 12/2/1857.

14. The 1853 kidnapping of Milton Howard and his family from their home in Muscatine is described in his testimony in a comrade's pension application (affidavit by Milton Howard, 12/17/1916, pension file of Harvey Brooks, WC825854, Civil War Pension Files, Record Group 15, National Archives and Records Administration), and in a 1978 interview by Lillian Justice with Milton Howard's niece, Dorothy Katherine Mitchell Childress, in Hope D. Williams, "An Oral History of the Black Population of Davenport, lowa" (1979), at the Davenport Public Library. Several Iowa newspapers reported Archie Webb's prosecution in 1863 for violating lowa law against black migration; see lowa State Register, 1/18/1863-2/3/1863; Burlington Daily Hawk-Eye, 1/24/1863, $2 / 5 / 1863$, and 2/6/1863; see also Justice of the Peace, Delaware Township, Polk County, Document Related to Removal of Free Negro, Jan. 1863, State Historical Society of Iowa, Iowa City; and Dykstra, Bright Radical Star, 199-200. 
black freedom was compromised. Repeated attacks against black Iowans reinforced the precariousness of their freedom, even with a vocal and politically active antislavery presence in the state.

It is not surprising, then, that black Iowans used the commemoration of emancipation in the British West Indies as an opportunity to criticize the persistence of slavery in the "land of the free." In 1860, at Davenport's first celebration of the anniversary of emancipation in the British West Indies, speakers contrasted British emancipation, "one of the greatest and most righteous deeds that ever graced the annals of history," with the unfinished work of the American Revolution. The celebrants gathered at Davenport "ask for nothing but freedom-the same freedom," they pointed out, "that the iron sons of '76 fought, bled, and died for; that which edifies a human, and places him in a position higher than a brute. ${ }^{\prime 15}$

When President Lincoln's Emancipation Proclamation committed the Union to ending slavery in the Rebel states effective January 1, 1863, African Americans could at long last celebrate the advent of black freedom at home. Former slave and Mount Pleasant resident Moses Mosely tried to capture the experience of that moment for liberated slaves: "Although nothing but freedom, it was marvelous in the imagination of the slave; the transition from slavery to freedom was beyond description. It filled the soul at least for a while; there was but little room for anything else until some of the excitement had a chance to work off."

As Mosely intimated, the Christmas and New Year's holidays of 1862-63 were especially jubilant. In Mount Pleasant, home of one of the fastest-growing communities of former slaves in wartime Iowa, celebration of the holidays was infused with and apparently overtaken by the prospect of slavery's end. Marked by several days of celebration that included "dancing every night and eating good dinners during the day," as well as several "colored balls," African Americans in that small community marked the advent of black freedom by "marching through town all night whooping, dancing, and singing 'Kingdom Coming,' with

15. Davenport Daily Gazette, 8/3/1860.

16. Moses Mosely, The Colored Man of America as a Slave and a Citizen of the United States (Mount Pleasant, 1884), 6-7. 
base [sic] and tenor drum accompaniment." "They made a heavy noise," observed a local newspaper. ${ }^{17}$

THE STATE'S rapidly growing black population built on antebellum experiences and wartime initiative to create a tradition that would produce hundreds of emancipation celebrations and commemorations in more than 30 Iowa communities over the course of the next century. ${ }^{18}$ That tradition was profoundly shaped by the proportion of former slaves in the state's population, which would continue to grow steadily during and at the close of the Civil War. Thousands of enslaved people fled bondage and the chaos of war in the lower Mississippi Valley and made their way to Iowa. ${ }^{19}$ Some made their own way, others were relocated as servants and farmhands by individual soldiers, military authorities, and civilian relief organizations, and still others chose to come north to Iowa in order to enlist in the state's black regiment. Joined by friends, family members, and returning black veterans at the end of the war, these former slaves joined Iowa's antebellum black population in the soulfilling celebration of slavery's demise.

17. The black population of Henry County, where Mount Pleasant is located, grew from 24 on the eve of the war to 262 at its close and to 401 by 1867 . Census of Iowa for 1880, 212. On the celebration, see Mount Pleasant Home Journal, $1 / 3 / 1863$. A celebration was also held in Des Moines on January 5 or 6 (contemporary accounts disagree), organized and attended by white abolitionists; it is impossible from existing records to determine whether or how many of the city's African Americans attended. Iowa State Register, 1/7/1863; Burlington Daily Hawk-Eye, 1/9/1863.

18. Based on research in numerous state newspapers, as well as the New York Times and the Christian Recorder (published by the AME Church), from the 1850 s through 1963 . Although by no means a complete survey of Iowa celebrations, my research has identified over 200 celebrations across the state of lowa.

19. Between 1860 and 1865, Iowa's black population increased from 1,069 to 3,608 ; by 1870 it was 5,762. For a fuller discussion, see Leslie A. Schwalm, "'Overrun with Free Negroes': Emancipation and Wartime Migration in the Upper Midwest," Civil War History 50 (2004), forthcoming. The upper Midwest was not alone in gaining a significant population of former slaves during and after the war. On black migration in the East, see Carol Faulkner, "The Hard Heart of the Nation: Gender, Race, and Dependency in the Freedmen's Aid Movement" (Ph.D. diss., State University of New York at Binghamton, 1998). The presence of former slaves in the postwar northern population suggests that our understanding of "northern" and "southern" black life may be overly simplistic. 
Several Iowa communities began holding emancipation celebrations after the war; Burlington, Clarinda, Davenport, De Witt, Dubuque, Fort Madison, Iowa City, Muscatine, and Oskaloosa were all occasionally holding celebrations by the late 1870s, some celebrating on August 1 , others on January $1{ }^{20}$ Other small communities hosted commemorations more sporadically, but their residents were probably no less likely to attend a celebration, as neighboring communities were often formally invited to gather at a central location. ${ }^{21}$ Like county and state fairs, Emancipation Day celebrations were marked by all the pleasures of sociability for a scattered rural population, especially one that had only recently gained freedom of movement and expression.

In Keokuk, home to the state's largest black population until the turn of the century, Emancipation Day commemorations gained particular momentum from the contested politics of race in the city's public sphere. ${ }^{22}$ Local blacks (including a significant

20. Given the difficulty of holding an outdoor celebration in the cold of midwestern winters, the August 1 celebration date might seem the most convenient choice. However, contemporary reports suggested a clear consciousness of the significance of the August date. In 1867, Keokuk blacks announced that by celebrating in August, both West Indian emancipation and the issuance of Lincoln's preliminary Emancipation Proclamation could be celebrated. Keokuk Daily Gate City, 8/1/1867. Other communities explicitly described their celebrations as commemorating West Indian, or Jamaican, emancipation. See $\mathrm{Du}$ buque Daily Times, 8/2/1882 and 8/2/1894.

21. In 1867 delegations from Davenport and Washington attended Muscatine's celebration (Muscatine Courier, 1/3/1867). In 1868 Des Moines invited black residents of Oskaloosa, Newton, Washington, Grinnell, and Chariton to participate in their commemoration (Iowa State Register, 7/21/1868), and Davenport invited residents of Rock Island and Moline, Illinois, as well as those of West Liberty to theirs (Davenport Daily Democrat, 7/31/1868). In 1872 the "colored fellow citizens of Davenport, Clinton, Lyons, Fulton, Moline, Rock Island, Muscatine, De Witt, Cedar Rapids, and Chicago" celebrated together at De Witt (Davenport Daily Democrat, 7/31/1872). In 1874 Mount Pleasant invited residents of Des Moines, Ottumwa, Burlington, and Keokuk (Robert D. Marshall, "Mount Pleasant, The Athens of Iowa, 1865-75" [master's thesis, University of Iowa, 1963], 51). In 1894 Oskaloosa organizers touted their celebration as a "statewide" event and invited more than 12 communities, including Des Moines and Keokuk, to their event (lowa State Bystander, 8/3/1894).

22. Keokuk was surpassed by Des Moines in the size of its black population in 1900; see Willis Goudy, “Selected Demographics: Iowa's African-American Residents, 1840-2000," in Outside In, 41. 
population of recently arrived former slaves) held their first emancipation celebration in August $1864 .{ }^{23}$ In 1865, as the city began planning its annual July Fourth celebration, Keokuk's black residents indicated their intention to participate in the parade. Keokuk's white fire company, however, did not welcome them. Feeling threatened by the potential integration of Keokuk's civic culture and the suggestion that citizenship was no longer an exclusively white privilege, the firefighters announced that they would not parade alongside blacks. Local black leaders refused to participate except on an equal basis, and the black community apparently agreed. ${ }^{24}$ But if Keokuk's black residents appeared to yield to white control over civic parades, they were not willing to relinquish their claims to citizenship or their right to the ceremonial civic space of the city's streets. By 1866, local black residents supported two annual commemorations, on January 1 and August 1 . Undaunted by the chill of the midwestern midwinter, they "turned out with flags and banners and transparencies" to parade through the city's main thoroughfares.

Emancipation celebrations arose out of struggles over race and civic culture in other Iowa communities as well. In Des Moines, after white abolitionists organized and dominated the city's first emancipation commemoration in 1863, black residents of the capital city organized their own July Fourth celebrations in 1864 and 1865 . In 1864 about 50 people attended, most of whom had "just been emancipated by the Rebellion and Federal bayonets." ${ }^{26}$ Not until 1866 did Des Moines blacks organize their celebration to fall on the August 1 anniversary of West Indian emancipation. After 1867, the August date would continue through the end of the century as the exclusive date for the local commemoration of "the anniversary of the freedom

23. Keokuk Constitution, 8/12/1863; Hubert H. Wubben, Civil War lowa and the Copperhead Movement (Ames, 1980), 153-54.

24. Faye Erma Harris, "A Frontier Community: The Economic, Social, and Political Development of Keokuk, Iowa, from 1820 to 1866 " (Ph.D. diss., University of Iowa, 1965), 389. July Fourth celebrations were sites of class as well as racial conflict; see the insightful assessments of Susan Davis, in Parades and Power, 40-48.

25. Keokuk Daily Gate City, 1/3/1866, 8/2/1866.

26. Iowa State Register, $7 / 7 / 1864,6 / 24 / 1865$. 
of the race in the West Indies and America."${ }^{27}$ The 1866 celebration in Des Moines was unprecedented in terms of the formality of the occasion, the full program of events, and its size (from four to six hundred people from the city and surrounding areas attended; Des Moines's black population in 1865 had been 91). A public procession marched through the city to musical accompaniment, waving flags made for the occasion. The celebrants assembled in front of the state capitol to hear several speakers, among them a black Civil War veteran and a white minister. After a dinner (a fund-raiser for Burns Methodist Episcopal Chapel, the city's first black church) and two patriotic songs by a "choir of colored misses, dressed in snowy white with blue trimming," the Emancipation Proclamation was read and music was performed by the "colored brass band." Several more speakers addressed the crowd, including two recent migrants from the slave South, the white editor of the local Republican newspaper, and Rev. S. T. Wells, also an ex-slave, who would become the first minister at Burns Chapel. ${ }^{28}$

The celebrations that were held closer in date to the anniversary of the Emancipation Proclamation often included what white observers described as "parades" and boisterous, streetbased festivities, but more orderly processions and formal programs quickly replaced such festivals after the war. The thousands of African Americans who migrated to Iowa during the Civil War had met with extensive opposition, including a rapid rise in racist rhetoric and assaults on blacks and the whites who employed them. Condemned in Democratic newspapers as a burden to the nation and a dependent population, Iowa's black residents would have been sharply aware that their every public appearance was under constant and critical white scrutiny and judgment. In such a context, black Iowans used the processions that became a core feature of Emancipation Day celebrations as a means of inserting themselves into the public sphere,

27. Quotation from a celebration announcement, Iowa State Register, 8/2/1876. In 1894 the celebration was held on September 20, close to the anniversary of Lincoln's Preliminary Emancipation Proclamation. Beginning in 1901, Des Moines began holding celebrations on or close to January 1 .

28. Iowa State Register, 8/2/1866. 
while also demonstrating to hostile whites that they could do so in a respectable manner. ${ }^{29}$

In describing the processions, contemporary observers captured their solemn quality: the participants "assembled at the African Methodist Church, formed in procession and marched through the principal streets"; "the dusky ranks moved in perfect order"; "the procession ... was large and orderly." When celebrations drew farming families from the surrounding countryside, the procession was more apt to include wagons, as was the case in Clarinda's 1871 celebration.

Early yesterday morning in every direction teams might have been seen making their way toward our city loaded with colored people who were concentrating at this place for the purpose of celebrating the anniversary of this great day to them, the Fourth of August. ... At about half past ten o'clock the procession was formed in what is known as Africa, and then moved toward town, making one grand revolution around the public square, presenting an appearance seldom witnessed by our citizens, when it "struck" for the grove east of Clarinda. The procession consisted of about 50 teams, all well filled with colored folks. ${ }^{31}$

The orderly appearance of these processions drew the eye of white observers; newspaper reports commented on the "wellappearing," "very creditable," and "respectable appearance" of the black Emancipation Day processions. ${ }^{32}$

If black Iowans assumed a more solemn posture in keeping with the mood of mid-nineteenth-century commemorations, we cannot overlook the likelihood that many may have also sought to impress white onlookers with what they knew would be viewed as a "respectable" appearance to support their larger claim on the political, as well as the public, sphere. In this endeavor, black Iowans echoed the efforts of African Americans

29. For Keokuk whites' hostility toward the growing African American population of the city, see, for example, Keokuk Daily Constitution, 9/5/1862.

30. Mount Pleasant Home Journal, 8/28/1865; Iowa State Register, 8/2/1866; Keokuk Daily Gate City, 1/3/1867.

31. Unidentified clipping, [1871], Black History Binder II, Nodaway Valley Museum.

32. Keokuk Daily Gate City, 1/3/1866; Mount Pleasant Home Journal, 8/28/1865; Iowa State Register, 8/2/1867. 
who sought public respectability in earlier periods as well as the similar efforts of their contemporaries across the nation. ${ }^{33}$

Yet white newspapers also reported "boisterous and disgraceful conduct" at Emancipation Day celebrations. There is, in fact, some evidence that not all participants in Emancipation Day events felt obligated to present an orderly or solemn appearance. William Butler, a 33-year-old plasterer of some modest success with a young wife and toddler, was one of three African American men whose "disagreement" at Keokuk's 1863 Emancipation Day picnic led to their arrest. Three years later, a "few irrepressible chaps" "got into a row," to the annoyance of the otherwise "well-disposed" crowd, which intervened in the fracas, disarmed the young men, and restored the peaceful tone of the gathering. When Muscatine's 1867 Emancipation Day speakers took the podium, they were interrupted by a "crowd of young men and boys" whose noisy and boisterous behavior "made it impossible to hear anything." Men were not the only disruptive figures; in 1875, Luella Lewis, a 23-year-old domestic servant, was one of a group of four African Americans arrested for "making a disturbance" at Keokuk's Emancipation Day activities. $^{34}$ These frustratingly incomplete reports of disruptive behavior may indicate disagreement within Iowa's black communities over whether Emancipation Day activities were primarily celebratory or commemorative, whether pleasure or respectability should take center stage. In at least a few instances, vernacular culture and an emphasis on the more exuberant pleasures of a community holiday won out over other concerns.

33. For a full discussion of the move away from boisterous street festivities to "respectable" processions among African Americans by the 1830s, see Kachun, Festivals of Freedom, 54-75; Rael, Black Identity and Black Protest, 54-81; and White, "It Was a Proud Day," especially 28-31, 34-41. The evolution of urban parades into a more elaborate ceremonial form by the eve of the Civil War is also discussed by Ryan in Women in Public, 20-23. Kachun, Festivals of Freedom, 236-48, also discusses the increasing concerns of black leaders with the projection of respectability in public commemorations that emerged in the $1880 \mathrm{~s}$.

34. Keokuk Constitution, 8/12/1863 (Butler appears in the 1860 census); Keokuk Daily Gate City, 8/2/1866; Muscatine Courier, 1/3/1867; Keokuk Daily Gate City, $1 / 3 / 1875$. 
IF THERE WAS such disagreement, several elements of the celebrations served to symbolize or produce a unified purpose. Music, for example, can sometimes bring discordant voices into unison. Whether on foot or in a wagon, a band nearly always accompanied-or led-Emancipation Day processions. Local and visiting brass bands, silver cornet bands, and drum corps regularly performed in processions and at dances that brought the day's events to a close. Their "martial music," "national airs," and "strains of sweet music" made the celebrations especially enjoyable. Marchers also occasionally sang and offered cheers. ${ }^{35}$

While music enlivened and unified the procession, flags, banners, costumes, uniforms, as well as decorated wagons and streetcars embellished the visual impact created by the marchers. Flags and "expressive banners" added to the "very creditable" impression made by Mount Pleasant's procession in 1865. Muscatine's 1867 procession included a prominent lithograph of Lincoln, the great "Emancipator." In Keokuk, the "holiday attire" of participants, the use of transparencies, along with flags and banners, helped make the procession "well appearing" in 1866, but by 1872 city blacks offered an even more elaborate appearance, including ladies on horseback, a carriage bearing the commemoration's key speakers, and a band of black men who bore the U.S. flag. In 1876, in Clarinda, the usual procession of wagons was also quite elaborate; one wagon was "beautifully festooned and decorated with stars and stripes, and loaded with colored ladies, with one up front carrying a large steel engraving of Lincoln." Costumes would continue as an element of Clarinda's celebrations in years to come; in 1885 and again in 1901 the procession made a dramatic impact with children in "gala costumes," as well as a costumed queen and goddess of liberty. ${ }^{36}$ Thus emancipation celebrations offered a feast for the eye and nourished rural midwesterners' cravings for social gatherings.

35. Christian Recorder, 2/4/1865; Iowa State Bystander, 8/9/1895; Mount Pleasant Home Journal, 1/3/1863.

36. Mount Pleasant Home Journal, 8/28/1865; Muscatine Courier, 1/3/1867; Keokuk Daily Gate City, 1/1/1866, 12/31/1871; unidentified newspaper clipping, Black History Binder, BH 007 (1876); transcribed clipping, Black History Binder, BH 0056 (1885); and 1901 program, Black History Binder, BH 110 (last three all at Nodaway Valley Museum). 
Food was also an important element of the day's events. Families brought their own picnic baskets, or a "grand meal" was provided. At several celebrations, the women of a local black congregation would provide the noontime meal or an evening supper, often as a fund-raiser for their churches, for the benefit of local needy black families, or for the local black school. ${ }^{37}$

Hospitality and culinary skill added significantly to the social and festive element of celebrations. In 1865 at Mount Pleasant, "the immense table was supplied with the substantials and delicacies of the season in great abundance, to which ample justice was done of the large crowd." Keokuk's August celebration -for several years involving an excursion to a nearby parkinvolved dinner baskets brought by each family. Dubuque's celebration offered an oyster dinner in 1870 and a barbeque in 1894. In 1896 in Des Moines, a fund-raising "grand barbecue" including ox, mutton, and pork drew a crowd and helped make the day successful. ${ }^{38}$

Food also served as one of the cultural symbols of display at emancipation celebrations. Like the solemn and orderly procession that reflected both the mood of the community and its performance of claims to respectability, the amount and variety of well-prepared food was offered not only in a gesture of nurturance for the local black community, but also a symbol of female accomplishment and black civilization. As the Mount Pleasant Home Journal noted in 1865, the repast provided by African American women was "worthy of any woman"; and a Des Moines celebration garnered praise for "a table beauteously spread and with cookery of the best quality. ${ }^{\prime \prime 3}$

37. Keokuk Weekly Constitution, 8/2/1882; Keokuk Daily Gate City 12/31/1871; Iowa State Register, 8/2/1866 and 1/1/1867; Davenport Daily Gazette, 12/29/1865; Dubuque Daily Times, 8/2/1882.

38. Davenport Daily Democrat, 1/4/1870; Dubuque Daily Times, 8/2/1894; Iowa State Bystander, 8/28/1896 and 9/18/1896; Keokuk Weekly Constitution, 8/2/1882; Keokuk Daily Gate City, 12/31/1871; Iowa State Register, 8/2/1866 and 1/1/1867; Davenport Daily Gazette, 12/29/1865; Dubuque Daily Times, 8/2/1882.

39. Mount Pleasant Home Joumal, 8/28/1865; Iowa State Register, 8/2/1876. On the cultural politics of foodways and the commodification of African American women's work in the kitchen, see John C. Super, "Food and History," Journal of Social History 36 (2002), 165-78; Doris Witt, Black Hunger: Food and the Politics of U.S. Identity (New York, 1999); and M. M. Manring, Slave in a Box: The Strange Career of Aunt Jemima (Charlottesville, VA, 1998). 
Several of Iowa's nineteenth-century celebrations-in Burlington, Clarinda, Des Moines, Dubuque, Mount Pleasant, and Oskaloosa-culminated in a distinctly secular fashion: with a dance or a more formal ball. In Des Moines, two balls were planned for the 187.6 celebration, one in Turner Hall and the other in the colored Masonic Hall. ${ }^{40}$

These various performative and material elements of expressive culture-processions, costumes, banners, music, food, and dancing - were joined by another key component, a diverse program of speech acts that can be grouped into five general categories: recitations; prepared and extemporaneous speeches; testifying; cheers and resolutions; and displays of the printed word. The single most common feature of postwar emancipation celebrations was the reading of the Emancipation Proclamation. (In 1876, Des Moines's commemorative exercises were suspended for two hours when it was discovered that the organizers had failed to bring along a copy of the proclamation to read. ${ }^{41}$ ) The reading was often given by an honored community member, and advance announcements of commemoration exercises tried to capitalize on the popularity of the reader as a draw to the program. ${ }^{42}$ Women were rarely invited onto the speaker's platform to deliver a keynote address, but they often read the proclamation as a part of the exercises. ${ }^{43}$ Along with the delivery of prepared and extemporaneous speeches at the celebrations, the reading of the proclamation was regarded as a performance, and those who performed knew they would be judged for the

40. Mount Pleasant Home Journal, 1/3/1863; unidentified clipping, [1871], Black History Binder II, and 1877 clipping, Underground Railroad Binder, both in Nodaway Valley Museum; Dubuque Daily Times, 8/2/1882; Burlington Daily Hawk-Eye, 8/2/1894; Keokuk Daily Constitution, 1/6/1864; Iowa State Register, 7/7/1864; Iowa State Bystander, 8/3/1894; Iowa State Register, 7/26/1876. The Tipton Advertiser, 12/3/1896, announced a "cake walk."

41. Iowa State Register, 8/2/1876.

42. See the announcement of Alexander Clark's role in exercises in Muscatine in the Muscatine Courier, 1/3/1867; Susan Mosely's role in Mount Pleasant's 1896 celebration in The Iowa Wesleyan, 10/15/1896; and the programs announcing local orators in the Iowa State Register, 7/31/1867, and the Keokuk Daily Gate City, $7 / 23 / 1874$.

43. See, for example, the listing of women as readers in the Muscatine Courier, 1/7/1869; the Tipton Advertiser, 1/2/1896; and, in Newton and Des Moines, as noted in the Iowa State Bystander, 1/4/1901 and 1/8/1909. 
quality of their reading. Assessments ranged from high praise for a preacher "of great power and eloquence," to the criticism directed at another speaker who read from a manuscript, a "tedious" delivery "which did not evidently delight any portion of the audience." ${ }^{\prime 4}$ Perhaps no element of Emancipation Day celebrations was as constant and unchanging as the requisite reading of the proclamation.

THE CENTRALITY of the Emancipation Proclamation to these celebrations raises several important questions about how the proclamation and its relationship to emancipation were understood, both in its immediate context and as the decades passed. Although historians continue to debate the document's intent and impact, most Americans today have neither read nor accurately understand the proclamation's significant limitations. In contrast, generations of black lowans who heard the proclamation read every year would have been closely familiar with the intricacies of the document's pronouncement of slavery's death in the Confederate states, the exclusion of the Union's slaveholding border states as well as Union-occupied regions of the South from its provisions, and its urging of non-violence and self-sufficiency for the former slave. ${ }^{45}$ The reading of the proclamation in the specific context of the other kinds of speech performance that occurred during emancipation celebrations provides a unique window into how black Iowans understood the process of emancipation, as well as the meaning of history and its commemoration to the Iowans who participated in Emancipation Day activities.

Iowa's nineteenth-century celebrants, like those across the nation, appear to have held a complex understanding of emancipation. Lincoln was typically portrayed as a great emancipator; from the lithographs and engravings of Lincoln that were

44. Iowa State Register, 8/2/1866; see also Burlington Daily Hawk-Eye, 8/2/1894; and lowa State Bystander, 1/4/1901 and 8/16/1901.

45. For a thoughtful overview of current popular and scholarly debates about the Emancipation Proclamation, see Ira Berlin, "Who Freed the Slaves? Emancipation and Its Meaning," in Union \& Emancipation: Essays on Politics and Race in the Civil War Era, ed. David W. Blight and Brooks D. Simpson (Kent, OH, 1997), 105-21. 
included among the flags and banners carried during processions, and the cheers of those who marched, to the speakers who memorialized the "cherished" author of the Emancipation Proclamation, Lincoln was honored as "the old man" who "stretched out his long arm and smote the monster [slavery] on the head with his Emancipation hammer, such a blow as none but Abe could strike." ${ }^{\prime 46}$

Yet if Lincoln was duly recognized as the author of the document that brought an end to American slavery, many agreed that it was God's hand that had moved Lincoln. "God wrought our freedom," asserted one speaker; "God willed it, and Heaven decreed it." It was a sentiment echoed in banners that read, "God says, Let the Oppressed Go Free" in an 1865 procession. Divine intent was also acknowledged by resolutions that honored Lincoln but thanked "the great Disposer of all events, that he put it into the hearts of the people, and the President of this country, to liberate the enslaved." ${ }^{\prime 47}$ The very fact that so many emancipation celebrations began the day in churches points to participants' belief that appropriate thanksgiving could only take place in God's house.

According to several of the earliest postwar celebrations, emancipation was a boon not only to the enslaved, but also to the entire nation. Celebrants in Keokuk in 1865 resolved that emancipation had been "indispensable to the cause of the Union, saving us alike from threatened foreign intervention, from disunity in executive policy, and from weakness in the prosecution of war." Democracy and the best interests of the nation had been served by Lincoln's proclamation. Three years later, speaker G. W. Guy asserted that the Emancipation Proclamation was "one of the greatest boons bestowed upon a Nation." Rhetorically asking "who should celebrate this day," Guy answered: "All who love liberty. ${ }^{\prime 48}$ Emancipation elevated the entire nation, not only the enslaved.

46. Christian Recorder, 2/4/1865; unidentified clipping, Black History Binder, BH 007, Nodaway Valley Museum; Keokuk Daily Gate City, 1/4/1868.

47. Christian Recorder, 2/4/1865; see also 1890 clipping, Black History Binder II, Nodaway Valley Museum.

48. Christian Recorder, 2/4/1865; Keokuk Daily Gate City, 1/4/1868. Guy was a teacher in Keokuk's black public school in 1868; between 1869 and 1873 he 
The complexity with which Emancipation Day celebrants understood the process of slavery's destruction and Lincoln's role in it is further suggested by the acknowledgment that emancipation required a significant change in public sentiment during the war; no speeches or resolutions suggested that the Union entered the war to free the slaves. ${ }^{49}$ Several Emancipation Day speakers, to the acclaim of their audiences, directly addressed the partial victory offered by Lincoln's actions. According to one speaker in 1866, the proclamation offered only a "partial development of the principles which our Fathers sowed in Revolutionary soil"; to another, Lincoln was the slaves' "neutral friend" rather than their second Moses. After all, Lincoln, on his election, "said if he thought tolerating slavery would maintain the Union, amen! and if destroying the same would do it, amen!" Only Jefferson Davis's refusal to surrender under Lincoln's terms (in which "every slave should be returned") brought slavery's end. "Davis is our modern Pharaoh, and through the hardness of his heart, God wrought our freedom," argued J. Carey of Keokuk, concluding that Davis, rather than Lincoln, was indirectly the "truest" friend of the slave. James Yancey of Fairfield agreed; although willing to pay "an eloquent compliment to President Lincoln," he nonetheless believed that "the Executive erred somewhat in his policy toward the slaves," perhaps referring to Lincoln's opposition to political and social equality, or his early insistence on pairing emancipation with colonization. ${ }^{50}$

served as the school's principal. Christian Recorder, 11/16/1867; "Schools," Bickel Collection, Keokuk Public Library. Politically active in the state's black convention movement, Guy occasionally served as a delegate to AME regional conferences. John T. Jenifer, D.D., Centennial Retrospect History of the African Methodist Episcopal Church (Nashville, n.d. [ca. 1916]), 114-15.

49. On the wartime change in public sentiment, see Christian Recorder, 2/4/1865.

50. Iowa State Register, 8/2/1866. Carey, a Baptist minister, was active in the state's black convention movement, and in 1869 defended the employment of black teachers in Keokuk's black public school. Keokuk Daily Gate City, 7/25/1869. Yancey, a Keokuk barber, moved to the state with his wife, Nancy, and infant daughter in 1857. Known locally as a skilled orator, he spoke at Emancipation Day celebrations in Keokuk, Mount Pleasant, and Des Moines before his death in 1878. Orville Louis Prill and Mary Barnes Prill, comps., Jefferson County Records, 13 vols. (Fairfield, 1966), 5:356-57; 1870 Federal Manuscript Census, Population, Ward Two, Fairfield, Jefferson County; Mount Pleasant Home Journal, 8/28/1865; Iowa State Register, 8/2/1866, 7/31/1867. 
More evidence of the limited effects of the proclamation was cited by a speaker in 1883 at Newton's celebration (which drew hundreds of participants from around the state). During an overview of the process of emancipation during the war, the speaker noted that northern hostility toward blacks during the war prevented African Americans from playing a more active role in the conflict; white soldiers refused to serve with them, and northerners had no intention of interfering with slavery when the war began. The Preliminary Emancipation Proclamation even raised the threat that the Confederate states might surrender according to Lincoln's terms and retain their slave property under federal protection. "How the colored people prayed that they might not surrender," the speaker recalled. ${ }^{51}$

But for black Iowans, the clearest evidence of the proclamation's "partial" victory lay in the limitations still placed on black citizenship by state and federal law at the close of the war. Denied suffrage, the right to hold office, and equal access to public schools and public accommodations, African Americans who celebrated the end of slavery in nineteenth-century Iowa were not reluctant to express their hope that "the liberties and rights of the colored people of the Union will soon be insured." Emancipation was only a partial vindication of the Declaration of Independence; but as a "free people," black Iowans insisted that they were "destined, at no remote period, to assist in the government of this country."

That destiny arrived in November 1868, when Iowa voters approved an amendment to the state constitution that removed racial qualifications from the franchise. After a series of court cases filed by black parents, Iowa's supreme court finally affirmed the right of black students to attend public schools in 1875. By 1884, black Iowans had won the right to serve in elective office and gained equal access to public accommodations. ${ }^{53}$

The rights and privileges that had been won in courts and at the state capital were, however, still frequently denied to black

51. Newton Journal, $8 / 8 / 1883$.

52. Iowa State Register, 8/2/1866; Keokuk Daily Gate City, 1/4/1868.

53. Acton and Acton, "A Legal History," 70-74; Hubert H. Wubben, "The Uncertain Trumpet: Iowa Republicans and Black Suffrage, 1860-1868," Annals of Iowa 47 (1984), 409-29; and Dykstra, Bright Radical Star, 219-37. 
Iowans, and speakers at annual emancipation celebrations continued to plead for full equality. White observers found it "discreditable" that the "old Republic Party hacks" continued to agitate at "any anniversary" celebration, but black Iowans did not hesitate to use the public stage provided by Emancipation Day activities to challenge discrimination and white racism in its various forms. James Yancey, a frequent speaker at Iowa celebrations, decried the "unholy prejudice" against African Americans and the "Copperhead lie" that blacks were not intelligent enough to have the right to vote. He also challenged white fears of miscegenation, noting in 1866 that there was "no danger of amalgamation, as the colored people do not love the whites sufficiently to marry them." The fact that Yancey himself was very light-skinned loaded this comment with an implicit charge against the sexual exploitation of black women by white men. ${ }^{55}$ More than 30 years later, John Thompson reminded "my Caucasian brethren" that while it was true that whites owned most of the nation's wealth, some of them got it by stealing "the labor of our forefathers for 243 years, paying them in nothing but a little piece of bacon and lots of hell."

ONE OF THE MOST DISTINCTIVE ELEMENTS of nineteenth-century celebrations was the special honor paid to former slaves and black Civil War veterans. A former slave was selected to serve as chief marshal of Keokuk's 1865 procession; Charles Davis, a young man still in active service in the 65th U.S. Colored Infantry at the time, was illiterate, but took pride in his military service and his battle-scarred face. ${ }^{57}$ At the Des Moines

54. Davenport Daily Democrat, $8 / 2 / 1872$.

55. Iowa State Register, $8 / 2 / 1866$.

56. Clipping, 8/4/1898, Ethnicity-Negro folder, vertical file, Keokuk Public Library.

57. Davis enlisted in January 1864 from Sangamon County, Illinois, was mustered into Company G, 65th U.S. Colored Infantry, and was mustered out on January 8, 1867. Bickel's Civil War binder, Keokuk Public Library. According to the 1870 census, at the time of Keokuk's 1865 celebration, Davis-born in Missouri-was in his twenties, was illiterate, and worked as a servant while residing in the household of a Georgia-born black family who had come to Iowa during or immediately after the war. Charles was described as a "familiar figure" in Keokuk. "He was very proud of his war service and displayed a rifle 
celebration in 1866 a Mr. Perkins spoke "lucidly and vigorously" about his "twenty-three years under the lash." S. J. Harris, a young man in his early twenties and a former slave, was also asked to address the crowd; he "spoke with some embarrassment but with considerable effect." At the same celebration, Rev. S. T. Wells-pastor of the community's black Methodist Episcopal congregation-brought a sharp yet effective tone of sarcasm to his observations about slavery:

He said he had lived in Missouri; had worked on the plantation to send his young master to college to become educated for the legal professions, so that he could learn how to catch runaway negroes with better facility; said master came back and sold his wife and children; then he (Wells) fell out with slavery, started North, and arrived there a little in advance of the Emancipation Proclamation.

Thomas Gordon Jones, who organized Emancipation Day celebrations in Clarinda, spoke in 1872 about his experience of slavery, giving "a general detail of the troubles, trials, and afflictions, and an interesting history of the liberation of their poor, degraded race." Jones would speak at many subsequent celebrations, elaborating on his personal experience; he did "his best to explain the difference between slavery and freedom." Former slaves were also invited to speak at Mount Pleasant's 1868 emancipation commemoration, but that element of the day's exercises was removed from public spectacle (and perhaps from white observers) and instead was conducted inside the AME church. It was described as an "experience meeting," in which "old slaves related incidents connected with their slave days and their lives as free men." ${ }^{158}$

Black Civil War veterans, like Charles Davis, were a regular feature of nineteenth-century celebrations. They reminded participants not only of slavery's recent shadow over their lives, but also of the role African Americans had played in destroying slav-

bullet wound scar on his face. Born in slavery, Charlie was a quiet, cheerful old fellow and friendly to everyone." Keokuk Daily Gate City, newspaper clipping and notes (1951), Negro History file, Lee County Historical Society, Keokuk.

58. Iowa State Register, 8/2/1866; clipping, 8/5/1871, Black History Binder II, Nodaway Valley Museum; clipping, 8/6/1901, Black History Binder, BH 110 , Nodaway Valley Museum; Mount Pleasant Home Journal, 9/25/1868; Henry County Free Press, 9/16/1868. 
ery, securing black freedom, and defending the nation. Several participants in Muscatine's 1867 procession made a signal visual impact as they marched "arrayed in army uniform, with swords, pistols, \&c. ${ }^{159}$ Mount Pleasant's 1868 emancipation celebration occurred on September 22, the anniversary of the Preliminary Emancipation Proclamation-and a few short weeks before white Iowans would vote on the constitutional amendment to extend the franchise to African Americans. Both former slaves and black Civil War veterans were important players in the day's events. The celebration began with a sunrise salute, as 12 black veterans formed a squad and fired their muskets, reminding Mount Pleasant's residents that African American men, who now sought the privileges of citizenship, had willingly shouldered a citizen's responsibilities during the war. ${ }^{60}$ The black veterans who paraded in uniform were publicly asserting their claims to manhood and the political privileges enjoyed by enfranchised men, but long denied to African American men.

The published record of observations about emancipation celebrations is less helpful in deciphering how nineteenthcentury black Iowans felt about the ways women could, and did, participate. We know that during the war, many black men of military age enlisted and were away from home, so women and children would have predominated in wartime processions and celebrations. ${ }^{61}$ And although black veterans who participated in emancipation celebrations received special recognition, there is no indication of any recognition of the role played during the war by many of Iowa's black women, such as the wives and family members who accompanied the state's black regiment in the South, working as laundresses, cooks, and nurses.

59. Muscatine Courier, 1/3/1867.

60. Mount Pleasant Home Joumal, $9 / 25 / 1868$. See also the invitation extended to Civil War veterans for Davenport's 1915 celebration in the Davenport Democrat and Leader, 12/27/1914, and the announcement that "former slaves and civil war veterans will be guests of honor" at the 1915 Des Moines celebration in the Register and Leader, 12/27/1914.

61. Hubert $\mathrm{H}$. Wubben quotes from a Keokuk newspaper making this point in Civil War Iowa and the Copperhead Movement, 153-54. William S. Morris has noted that nearly all of the African American men of military age in Iowa in $1863-700$ out of a total black population of about 1,500-enlisted during the Civil War. Morris, "Black Iowans in Defense of the Nation," in Outside In, 92. 
When women were given-or assumed-special roles in celebration activities, it was often as costumed female symbols. On horseback and in decorated carriages and wagons, women and girls appeared as living symbols of Republicanism, or of the Goddesses of Liberty and of Plenty. If we are tempted to regard this as a passive or purely decorative role, we need only remember how white Iowans viewed the former slave women who came into the state during and immediately after the Civil War. When they gathered near Union lines in the South, exasperated military authorities sent them north to fill the places left vacant by male laborers who had enlisted. Sending African American women north meant they could become "a means of usefulness rather than a mere source of encumbrance. ${ }^{162}$ The men and women who hired them in Iowa employed them as farmhands, laundresses, and servants. ${ }^{63}$ Black women who came into Iowa were expected to work, often in circumstances and occupations that were regarded as demeaning to white, middle-class women and denigrating to their womanhood. When African American women sewed elaborate costumes for themselves and their daughters to wear as goddesses and queens, to be carried by horses and wagons rather than march on foot, they may have been claiming for themselves and their daughters a privileged womanhood that whites actively denied them.

One especially important role that African American women played in Iowa's nineteenth-century emancipation celebrations was in organizing and cooking the meals that were offered either gratis or as a fund-raiser. Such meals displayed the skill and accomplishments of the women who prepared them, but also revealed the behind-the-scenes organizing conducted by African American women in advance of the celebrations. Newspaper reports often indicated that the women who prepared

62. Maj. Gen. B. Prentiss to Gen. J. Schofield, 6/16/1863, Ser. 4664, Letters Sent, Dept. of Ark., Dist. of Eastern Ark., vol. 37/96, 97, 98, DArk, RG 393, pt. II, National Archives and Records Administration, Washington, DC.

63. Mrs. John Shane to Annie Wittenmyer, 10/27/1862, 12/8/1862, and 3/20/1863; and Wm. W. Sandford of Bentonsport to Annie Wittenmyer, n.d. [filed in folder 14], both in Annie Wittenmyer Papers, State Historical Society of Iowa, Des Moines. See also the Keokuk Weekly Gate City, 3/25/1863. 
these meals were affiliated with church women's groups, significant evidence of the role that women in black congregations played in creating and maintaining the tradition of Emancipation Day commemorations. ${ }^{64}$

NINETEENTH-CENTURY emancipation celebrations were dynamic in form, location, and context, but the pace of change in the form and purpose of the celebrations accelerated at the end of the century. By the early twentieth century, the celebrations had evolved into significantly different events. The changes can generally be traced to three developments: (1) the growing urban population of Iowa blacks and an increasingly sharp differentiation between rural and urban black communities and the ways they celebrated or commemorated emancipation; (2) the advancing age of the generation of black Iowans who had experienced slavery, and their declining role in the celebrations; and (3) a change in the representation and purpose of history in Emancipation Day activities.

During and immediately after the Civil War, the former slaves who migrated to lowa settled predominately in its older eastern cities and towns-Davenport, Dubuque, Iowa City, Keokuk, Mount Pleasant, and Muscatine. With the exception of Davenport, the black population of those towns peaked by 1880 and began to decline. After 1880, the number of farm-owning families in Iowa would remain fairly consistent through the Great Depression (300 in 1880; 280 in the 1930s), while the small but cohesive communities of former slaves that had emerged in the eastern portion of the state would decline, particularly as mining, railroad, and packinghouse employment opportunities opened elsewhere from the 1870s onward. Southern Iowa's counties affected by the coal-mining boom saw somewhat later peaks, but they, too, began a decline that accelerated with the closing of Buxton's mines in 1918. Even Clarinda, whose black population remained fairly steady through the turn of the century, had begun to decline by 1920 . In contrast, the black population of Des Moines, as well as Sioux City, continued to grow,

64. Henry County Free Press, 9/16/1868; Davenport Daily Democrat, 1/4/1870; Dubuque Daily Times, 8/2/1882. 
and with significant in-migration from Holmes County, Mississippi, Waterloo also saw significant growth. By 1900, however, Des Moines had become home to 64 percent of the state's black urban population-and 90 percent by $1940 .^{65}$

But it was not simply the redistribution of Iowa's black population away from the eastern towns and cities that altered the nature of emancipation's commemoration. Rather, it was the combined impact of generational shifts, urbanization, and the growing popularity of racial uplift ideology that prompted change in their content and purpose.

In Des Moines, for example, it seems that the aging population of the community's earliest black residents shaped the orientation of emancipation celebrations from the late 1880 s to 1899. The Des Moines Old Settlers' Society-an all-black associationwas organized in 1887, when, according to one of the association's presiding officers, "colored old settlers were at such a premium in the township of Des Moines." The city's August emancipation celebration became focused on the reunion of old settlers and their families, a picnic that included speakers who recalled the city's earliest black residents from the war years. Although the white newspapers reporting on the celebrations and their participants, saturated with the racist language and imagery of white popular culture, have to be read with caution, it appears from their reports that neither Lincoln nor the Emancipation Proclamation was a main topic of discussion. When, as one newspaper report noted, "the Colored Men remember the Emancipation Anniversary," they recalled a narrative of local events and local heroes. Even so, it was a popular event; "several hundred" attended in 1890, and the "feast of good things" was pointed out as an example of the riches that the city's old settlers had never had "'befoh' the wah."' "It must be a satisfaction," noted a reporter, "that in their old age they see their children's tables heaped with plenty and to spare, and luxuries as well as necessities." By the late 1890 s, Society president R. N. Hyde expressed his hope that the "younger generation that was rapidly trenching upon the old folks' domains would perpetuate

65. Valerie Grim, "African-Americans in Iowa Agriculture: A Portrait, 18302000," in Outside In, 167-89; Goudy, "Selected Demographics," ibid., 40-41. 
the good name which was being left to them by pioneer colored men and women." ${ }^{\prime 66}$

The children of former slaves also began to take their place in Iowa emancipation celebrations; Susan Mosely Grandison, daughter of former slaves who had come to Mount Pleasant during or just after the war, spoke at the Mount Pleasant gathering in 1896. ${ }^{67}$ The young girls who had dressed up in costumes to participate in the celebrations of the 1870 s had matured into young women who now took to the speakers' platform. ${ }^{68}$ So, too, the sons of Iowa's black war veterans became keynote speakers, as the aging veterans themselves were given increasingly honorific, less physically demanding roles, seated behind the speakers' platform rather than marching and offering sunrise salutes, as they had in earlier decades. ${ }^{69}$ In 1899 , Boone's small black community extended a special invitation to "the old soldiers" to attend their celebration, which included an address on Iowa's black civil war regiment. In 1915, Des Moines's celebrants extended a special invitation to black Civil War veterans to take reserved seats on the speakers' platform. Keokuk's 1922 celebration included two veterans who not only were seated on the speakers' platform but also led the celebrants in singing "Rally Round the Flag Boys. ${ }^{70}$

In the smaller community of Clarinda, Thomas Gordon Jones also noted the generational change in his 1890 Emancipation Day address: "They have throwed the old man up here to talk a little to you. They know this fellow has seen the elephant. No use trying to make much of myself but I am trying to elevate my children. Some of them you saw this morning on the plat-

66. Iowa State Register, 8/2/1890; Des Moines Leader, 8/12/1898. Des Moines was not the only Iowa city in which African Americans joined Old Settlers' societies: African Americans had attended Muscatine's Old Settlers' Reunion at least since 1879, both as "Old Settlers" (people who arrived prior to 1840) and as their descendants. Old Settlers Register, Musser Library, Muscatine.

67. The lowa Wesleyan, 10/15/1896.

68. Iowa State Register, $8 / 2 / 1876$.

69. In 1922, for example, Alonzo Draine, son of one of Iowa's black Civil War veterans, was a keynote speaker at Keokuk's celebration. Keokuk Daily Gate City, 9/23/1922. By 1890, less than 30 percent of black Civil War veterans were still alive, according to David Blight, Race and Reunion, 194.

70. Iowa Bystander, 1/13/1899, 12/29/1915; Keokuk Daily Gate City, 9/23/1922. 
form. ${ }^{\prime 71}$ Yet if Jones was willing to share the platform with the next generation, he was still unwilling to relinquish it. A former slave from Missouri, Jones was one of the more than 150 African Americans - the vast majority of them former slaves-who had settled in Page County during and immediately after the Civil War, and had become active in Clarinda's emancipation celebrations (which had started by 1866). He played a central role in organizing the community's celebrations for the next 35 years, often with the unacknowledged assistance of his wife, Eliza. At the time of his wife's death, her obituary noted their importance to the community's tradition of celebrating emancipation: "In the history of our town there are no more vivid incidents than the celebrations of Emancipation Day which were promoted and managed by her husband with her loyal assistance when there were great parades of picturesque floats; immense crowds and well-known speakers." "72

Unlike other communities, where emancipation celebrations became increasingly formal and sedate, Clarinda's festivities grew larger and more spectacular, even into the 1920s. Beginning in the 1890s, the processions, bands, choirs, speeches, meals, and dances that were standard features of the day were joined by ball games between town clubs; by 1900, fireworks and fair rides were added to the festivities; and by the 1930s, the celebration included a wide range of sporting activities, including men's and women's ball games, automobile and foot races, horseshoe pitching, and bicycling. Although they never lost the core features that separated them from the summer fairs they so closely resembled, Clarinda's emancipation celebrations evolved along a path unlike that followed by other black communities in the state.

Perhaps part of the explanation for the singular development of Clarinda's Emancipation Day tradition rests with the whites who attended-and vastly outnumbered the black participants. Whites had probably always attended Clarinda's celebrations; by 1870 white speakers were among those offering addresses, and by the early 1870 s the whites who attended ap-

71. Unidentified clipping, [1890], Black History Binder, BH 014, Nodaway Valley Museum.

72. Unidentified and undated clipping, Black History Binder, BH 002-A, Nodaway Valley Museum. 
parently outnumbered the African Americans. In 1877, when whites attending outnumbered blacks by ten to one, area residents apparently settled on a practice that continued for some time: whites left the festivities in the early evening, while black participants stayed "until a late hour." Whites must have had varied reasons for attending that changed over time, but beginning in the 1870s, Clarinda's newspapers portrayed the celebrations in the pejorative tones that foreshadowed the "plantation school" literature of Thomas Nelson Page and others, a literature that waxed romantic about a fictional antebellum South where slaves were happy, contented, and loyal to their masters. ${ }^{73}$

Such contemporary newspaper reports indicate that the white residents Page County were profoundly sentimental about a very different version of the past than the version commemorated by African Americans. The newspapers of this Missouriborder county rendered African American speech in dialect and described the dances that closed the celebration as "a regular oldfashioned plantation hoe-down" and as cakewalks. "Music and hilarity reigned supreme," noted a report of the 1877 celebration, "and it was really amusing to see the colored faces brighten up and hear them chuckle and laugh" as they listened to "negro plantation songs." In 1878, the local paper insisted that "a platform and a violin where a negro can shake his foot have more attractions than all the speakers in the country." For many whites, who apparently viewed the emancipation celebration as an opportunity for amusement and entertainment in observing African Americans "at play," this was undoubtedly true. ${ }^{74}$ The programs for the town's emancipation celebrations continued to include a more serious component, but from the perspective of white reporters who described the city's celebrations, emancipation had "completely dispelled all ... sad feelings" from the minds of former slaves and led to "uncontrollable joy." Since few blackauthored records allow us insight into the experience of Cla-

73. Unidentified clippings, [1871 or 1872] and 1877, Black History Binder II, Nodaway Valley Museum. On the plantation school, see Blight, Race and Reunion, 221-27.

74. On white audiences and their responses to black performers, see Alessandra Lorini, Rituals of Race: American Public Culture and the Search for Racial Democracy (Charlottesville, VA, 1999), 168-72. 
rinda's African American community, we can only postulate that the fictional Old South that white audiences believed they saw reenacted during Emancipation Day celebrations was an example of white observers missing the text that African Americans directed toward each other. Since the celebrations continued to be very popular with African Americans throughout the region, and were often used as fund-raisers for the local black community, Clarinda blacks may have chosen to retain the serious content of their celebrations but to emphasize the festivities that black and white alike enjoyed, and reap the benefits. ${ }^{75}$

Clarinda was not the only community where white observers vastly outnumbered African American participants in emancipation celebrations. In 1900 the white residents of nearby Burlington Junction, Missouri-a town with (reportedly) one black resident-invited Clarinda's black residents to help that town hold its own Emancipation Day celebration; the event was subsequently pronounced "one of the grandest of the season." In 1901, the small black community in Leon (in Decatur County, Iowa), "assisted by the good white people," held its first emancipation celebration. Of the nearly 7,000 people who attended, "only a few colored people were there," even though Nelson C. Crews of Kansas City, "one of the best colored orators of the West," was to speak. Even in the larger eastern towns of Keokuk and Dubuque, large numbers of whites attended emancipation celebrations. ${ }^{76}$ In their eagerness to indulge in their fantasies about black life and culture, whites helped displace African American memory and history from Iowa's Emancipation Day celebrations.

WHAT HISTORIAN DAVID BLIGHT has described as the battle for the memory of the war had something of a "last stand" at Iowa emancipation celebrations in the 1890 s. As the increasingly popular culture of the Lost Cause combined forces with the

75. For pejorative reporting about Clarinda Emancipation Day celebrations, see, for example, unidentified clippings, [1872, 1877, 1878, and 1901], Black History Binder II, Nodaway Valley Museum.

76. Unidentified clipping [1900], Black History Binder, BH 103, Nodaway Valley Museum; Iowa State Bystander, 8/17/1900, 8/16/1901; Keokuk Daily Gate City, 8/2/1866; Dubuque Daily Times, 8/2/1894. 
exaggerated mythology of the Underground Railroad, American histories and memories of slavery were distorted by a film of white nostalgia for the past-for a time when slavery evoked northern white heroism, and when the devoted slaves of the South nurtured whites rather than confronted them.

In 1894, in the face of this tendency, Albion Tourgee was invited to give the keynote speech at the Des Moines emancipation celebration. The nationally known Union veteran, carpetbagger judge, and writer was an advocate of the war's emancipationist vision. As reported in the Iowa State Bystander,

Judge Tourgee, author and humanitarian, delivered one of his famous lectures at Calvary tabernacle Thursday evening on the socalled race problem. No man is better prepared than he to discuss the Negro subject, as his lifework almost entirely has been devoted to the amelioration of this persecuted race.... Among other things the judge spoke feelingly of the race he so dearly loves, and paid a glowing tribute to the marvelous achievements and advancement of a people who, he declared, had borne more misery and with a less vindictive spirit than any race of people who ever lived. History records the Negro race as the greatest race living. The wrong and injustice done them would not be tolerated by any other race. Mr. Tourgee laid stress on the fact that the colored people should visit the white churches and other kindred organizations and societies at least once a month, in order that they may make friends and not be a curiosity, but rather a fixture in the respective edifices. Do not hesitate to go anywhere on account of color."

Like Tourgee, in 1898, John Thompson, editor of the Bystander, compelled his audience at Keokuk's Emancipation Day celebration to return, in their thoughts, to the history and brutality of slavery; but Thompson concluded his stirring address on a note of racial uplift and a profoundly conservative politics of race.

By the turn of the century, with the passing of the generation of African Americans who had once been enslaved, slavery was more often a topic noted in the obituaries of black Iowans than in the record of Emancipation Day celebrations. Although

77. Iowa State Bystander, 9/21/1894. On Tourgee, see Blight, Race and Reunion, 217-21. The Bystander had been named in honor and approval of Tourgee's column, "The Bystander's Notes," in a Chicago newspaper. Jones, "Equal Rights to All," 76. 
black Iowans had long sustained both a public and a more private memory of slavery, war, and emancipation in a remarkably wide range of venues, the passing of this generation contributed to a shift in Emancipation Day activities. ${ }^{78}$ Black Iowans moved away from celebrating the end of slavery (with an emphasis on surviving it), and instead emphasized emancipation as freedom's beginning, a celebration of new opportunities for black America, with fewer and fewer references to the slave past. After almost 40 years of emancipation celebrations, black Iowans now preferred to describe Emancipation Day as "our natal day." As the editor of the Iowa State Bystander noted in reference to the upcoming New Year of 1900,

the colored American birthday began on New Year's day, 1863; nearly 4,000,000 slaves were declared free and a citizen, clothed with both civil and political rights. No one but the emancipated can fully understand and appreciate the full meaning of the word free citizen. ... We as a race ought too [sic] feel proud of this day. Since our emancipation we have made good progress, considering the environments, disadvantage, racil [sic] hatred and color prejudice. It may be true that we could have done better, yet we have done better than any other race under similar conditions. To our friends we say, do not expect too much, for we are coming slowly but surely. Remember that it takes some little time to develop a race or an individual. All we ask now is an equal opportunityopen your shops, factories and offices to him or her who have the necessary qualification. ${ }^{7 "}$

Accompanying the turn away from emancipation celebrations that assessed the history of slavery, the causes of the war, the haphazard and unpredictable process of emancipation, and the Reconstruction-era struggle for civil rights was a turn toward racial uplift ideology. Keynote speakers began focusing on what the race might achieve and the characteristics that were necessary for success. Rev. W. J. Laws, speaking at Burlington's 1894 celebration, "urged upon his fellow negroes the appreciation of

78. Black lowans sustained the memory of slavery in everything from political pamphlets and memoirs to postbellum slave narratives and obituaries, as well as in the conversations and family gatherings recalled in the pension records of black Civil War veterans and their families.

79. Iowa State Bystander, 12/29/1899. 
the fact that the successful outcome of the race questions rests upon the negro himself; that by sobriety, industry, frugality and perseverance, assisted by a firm determination to acquire knowledge and become educated, the colored race will be able to dictate the terms of its own destiny, and to wring from the white race that recognition of equality in all things which it would then deserve." ${ }^{80}$

The turn toward the theme of uplift in Emancipation Day celebrations was also a reaction by Iowa's more urban-based black communities to the kind of dynamic we see in Clarinda, where demeaning, racist imagery dominated white accounts of African Americans and their activities during these celebrations. In Des Moines, the Emancipation Day activities of the Old Settlers Society also became targets of this kind of reporting. In 1898 the Des Moines Leader portrayed their picnic as "a good honest colored picnic," including "pickanniny stock of the first water," the draw of "'more wattahmellon an' chicken than you evah saw,'” and dancing: "'Miss Melinda Johnsin' went a-swingin' down the lane,' as in the good old days when plantation Topsy cut the pigeon wing. ${ }^{181}$

The middle-class and aspiring population of black Iowans in its cities would have understood these demeaning images as a mockery of their achievements, a denial of their aspirations, and a refusal to acknowledge the cultural authority that black lawyers, ministers, college graduates, and professionals were claiming. When black Iowans offered Emancipation Day speeches that elaborated on the ideas of racial uplift, they were combating such demeaning images of African Americans. As historian Kevin Gaines explains, advancing uplift ideology was also a "struggle for a positive black identity in a deeply racist society, turning the pejorative designation of race into a source of dignity and self-affirmation through an ideology of class differentiation, self-help, and interdependence. ${ }^{1 / 22}$ Elite blacks argued for the possibilities of cultural assimilation, in which class-based

80. Burlington Daily Hawk-Eye, 8/2/1894.

81. Des Moines Leader, 8/12/1898.

82. Kevin K. Gaines, Uplifting the Race: Black Leadership, Politics, and Culture in the Twentieth Century (Chapel Hill, NC, 1996), 3. My reading of uplift ideology draws heavily from Gaines's insightful work. 
cultural differences rather than a biological notion of race would become the measure against which black Americans could strive for respectability. African Americans who could measure up to the same bourgeois values embraced by white Americans were entitled to the same prestige. Middle-class blacks tried to reinforce their claims to citizenship by accepting and advancing class differentiation. In 1898 John Thompson-in classic "uplift" terms-urged those in attendance at Keokuk's Emancipation Day celebration to pursue self-reliance and self-support; "act well our part in little things and the larger ones will be forced to open to us." Pursue education, wealth, and land ownership, he urged; become owners of large farms, stores, houses, factories, mines, and shops. "We do not ask for social equality, but simply business and public equality." But here Thompson's message of uplift and assimilation pivots back to history and the crucial difference between black and white experiences of history. Referring back in time to the exploitation of enslaved people by white slave owners, Thompson declared, "We are to make the history of our race." To this son of a slave - one of Iowa's most accomplished sons-that history should acknowledge both the cruelty of the slave's experience as well as the accomplishments of a freed people.

FROM THE TURN OF THE CENTURY until the early 1930s, new cultural brokers took over the planning and organization of emancipation celebrations in Des Moines. Responsibility shifted from the Old Settlers Society to the AME church (1901, January 1915), the city's black literary society $(1902,1904)$, and then to race and civil rights organizations: first the Afro-American Council, forerunner to the Niagara movement (1907-1910); then The (Washingtonian) Negro Business League (1914); and, beginning in September 1915, the NAACP. ${ }^{83}$ Emancipation cele-

83. The Afro-American Council was formed in 1898, a rebirth of the AfroAmerican League that organized out of a national meeting convened in Chicago in 1890 by T. Thomas Fortune, editor of the New York Age. Without adequate support, the League failed, but the Council was organized on the same basis, as a challenge to the disenfranchisement of southern black men and in protest against lynching, the chain-gang system, and discrimination in public schooling and accommodations, as well as wage and occupational discrimina- 
brations moved indoors, replacing the picnics and processions that had marked the nineteenth-century claim on the public sphere with a more decorous, orderly, and formal presentation. Papers were now read (a practice that had earned a nineteenthcentury speaker the disdain of his audience), and formal vocal solos, choir presentations, and recitals replaced the cheers, marching bands, and personal testimony that had been key components of earlier celebrations.

At the fiftieth anniversary meeting in Des Moines in 1913, "there was neither boisterous declamation nor boisterous applause. Moderation prevailed in everything. It was a determined, thoughtful, ambitious body of Americans who were rejoicing over fifty years of progress and looking forward hopefully." The program offered speeches on the progress of the race, as well as a display in which one hundred children "representing the fifty years of our freedom" and "the future hope of the race" were offered as the evening's entertainment. No one talked about the slave past. Fifteen hundred black residents of Des Moines attended that celebration. This and other twentieth-century programs were published in advance, and the addresses focused on the post-emancipation life of African Americans, as well as their future. ${ }^{84}$

Despite the change in the content of the history and collective memory that was forged in Progressive-era emancipation celebrations, black history remained an important theme for the

tion. Iowa delegates, including Bystander editor John Thompson, attended the League's 1890 meeting in Chicago as well as the Council's conventions in Indianapolis in 1900 and in St. Paul in 1902. See the Official Compilation of Proceedings of the Afro-American League National Convention, Held at Chicago, January 15, 16, 17, 1890 . . (Chicago, [1890]); and Cyrus Field Adams, comp., The National Afro-American Council, Organized 1898. A History of Its Organization . . . (n.p., 1902). Booker T. Washington organized The National Negro Business League in 1900 to advance the economic interests of elite businessmen. See Louis $R$. Harlan, Booker T. Washington: The Making of A Black Leader, 1856-1901 (New York, 1972), 266-71; Lorini, Rituals of Race, 194-207; lowa State Bystander, 1/8/1915. The NAACP was organized nationally in 1909; a Des Moines branch was formed in 1915. See Jack Lufkin, "The Founding and Early Years of the National Association for the Advancement of Colored People in Des Moines, 1915-1930," Annals of Iowa 45 (1980), 439-61.

84. Iowa State Bystander, 1/3/1913, 12/6/1912. For other examples, see programs published in the Bystander, 1/8/1904, 12/25/1908, 12/31/1909, 12/26/1913. 
civil rights organizations that planned Des Moines's emancipation celebrations. S. Joe Brown-lawyer, president of the Iowa branch of the Afro-American Council, and one of the founding members of the Des Moines branch of the NAACP-had been active at least since 1907 in an effort to make Emancipation Day a national celebration. In keeping with that effort, he issued a call in December 1909 for "all local Afro-American Councils, Negro Churches, Clubs and other race organizations [to] observe the first day of January, 1910," including the reading of the Emancipation Proclamation, singing of patriotic songs, and addresses "commemorative of that memorable occasion." ${ }^{85}$

The Des Moines branch of the NAACP not only organized New Year's Day emancipation celebrations in the city; it also added to the commemorative calendar an annual LincolnDouglass Anniversary celebration in February. ${ }^{86}$ Portraying Abraham Lincoln and Frederick Douglass as the joint emancipators of the race, the NAACP branch fostered a collective memory of emancipation that focused far more on a national, heroic narrative of black history than one rooted in local or regional experience or the slave past. This national focus would carry over into its promotion of Negro History Week activities

85. Iowa State Bystander, 1/4/1907, 12/3/1909. In its first year, the Des Moines branch of the NAACP initiated an important (although ultimately unsuccessful) legal challenge to the showing of The Birth of a Nation in city theaters. The film, based on Thomas Dixon's novel, The Clansman, offered a distorted, "Lost Cause" portrait of Reconstruction, caricaturing black men as rapists and attempting to justify lynching. See Lufkin, "Founding of the NAACP in Des Moines," 450-52. Sue Brown, Joe's wife, who was also active in the NAACP, chaired the Advisory Board of the Frederick Douglass Memorial and Historical Association in 1923, organized to maintain and preserve the Douglass home as well as the Douglass papers. Mrs. S. Joe Brown to Hon. J. W. Johnson, 7/31/1923, frame 634, reel 10, part 12, series C, NAACP Papers. The Des Moines Interracial Commission, organized in 1924, called for "the introduction of a course in Negro History into the Des Moines Public Schools" as one of its 14 "Desiderata." S. Joe Brown et al., comps., Twenty Years of Interracial Work in Des Moines, Iowa; Brief History of the Des Moines Interracial Commission (n.p., 1944).

86. Existing newspaper accounts and NAACP records-which may be incomplete-document NAACP commemorative activities from 1915 through 1928 and in 1930,1932, 1935, 1945, 1955, and 1963. The NAACP's involvement with the memory and commemoration of black history, as well as the changing form in which that history was presented, is also discussed in Lorini, Rituals of Race, 208-56; and Blight, Race and Union, 361-97. 
in 1945 as well. One important departure from this national focus, however, occurred during the branch's activities in 1931 and 1932, when the branch erected a booth at the Iowa State Fair, with a variety of displays addressing black progress and the struggle for civil rights.

The civil rights organizations that assumed responsibility for Emancipation Day celebrations (in Des Moines, but also in Newton, Fort Madison, and Waterloo) not only relocated the celebrations into black churches and halls and advocated the importance of a national narrative of black history, but also helped alter the gender politics of emancipation celebrations in Iowa. Both the Afro-American Council and the NAACP contributed to the changes in the black public sphere that made it increasingly possible for African American women to assume more public roles in emancipation celebrations. Although they still prepared meals and performed musical pieces that demonstrated their refinement, women also led devotional exercises, read the proclamation, and even delivered addresses-on such topics as citizenship, the history of Iowa's black regiment, and "the Negro problem." At the "Grand Golden Jubilee Celebration of Emancipation" held in Des Moines in 1913, Mrs. J. B. Rush addressed the audience on the topic of "Women's Progress," and the following year Sue Brown gave a speech, "Forward Movement of Colored Women." ${ }^{\prime 88}$

Black women were not simply beneficiaries of enlightened race organizations; at the turn of the century, they took a more public and authoritative role in Emancipation Day exercises because they had assumed those roles in the larger black public sphere. From the club movement that African Americans initiated in 1890 (forming a statewide federation in 1902), to their predominance in the African Methodist Episcopal Church's

87. The branch also distributed a pamphlet it had prepared for the fair, A Few Facts about Iowa Negroes. The pamphlet was primarily given over to brief biographies of leading black men and women, rather than a historical narrative about African Americans in the state. Ten thousand copies of the eight-page pamphlet were distributed, and the NAACP won two prizes at the 1932 fair. Frame 1018-26, reel 10, part 12, series C, Papers of the NAACP.

88. Iowa State Bystander, 1/3/1913, 12/26/1913. See also the programs described in the Bystander, 1/4/1901, 1/1/1904, 1/4/1907, 1/1/1909, 1/1/1910, 1/3/1913. 
Sunday School movement in Iowa and their central role in the Iowa branches of the Afro-American Council and the NAACP, black women in Iowa had created and expanded the opportunities through which they could both organize and lead their communities. ${ }^{89}$ Through this work, they also secured influence over how African American history was remembered and collectively commemorated. In 1931, the women of the Des Moines branch of the NAACP took complete charge over the planning and presentation of Emancipation Day exercises. ${ }^{90}$

IN DES MOINES and elsewhere across the state, Emancipation Day activities became far more sporadic after 1935, and were eventually supplanted by Lincoln-Douglass Day celebrations. Although a few events-including Lincoln-Douglass Day and Negro History Week-seem to have been revived at the end of World War II, they died out once again, until the 1950s. Yet the centennial anniversary of American emancipation did not pass unnoticed; in fact, the state's NAACP branches conducted an extraordinary number of events that year, including Emancipation Day, Lincoln-Douglass Day, a celebration of the anniversary of the Supreme Court's Brown v. Board of Education decision, and participation in the August March on Washington and Human Rights Day on December $15 .^{91}$

Although Emancipation Day celebrations continued in some American communities, during the years following the Second World War, Iowa's commemorations had become infre-

89. On the African American women's club movement in Iowa, see Anne Beiser Allen, "Sowing Seeds of Kindness-and Change: A History of the Iowa Association of Colored Women's Clubs," Iowa Heritage Illustrated 83 (2002), 213. On the AME Sunday School convention, see the Iowa State Bystander, $5 / 12 / 1899,6 / 9 / 1899,6 / 22 / 1900$. On women and the Afro-American Council, see the lowa State Bystander, 8/25/1899, 12/3/1909. On African American women and the Des Moines NAACP Branch, see S. Joe Brown, History of the Des Moines Branch, National Association for the Advancement of Colored People (n.p., 1927). Two excellent sources on twentieth-century African American women's activism in secular and denominational organizations are Deborah Gray White, Too Heavy a Load: Black Women in Defense of Themselves, 1894-1994 (New York, 1999), and Evelyn Brooks Higginbotham, Righteous Discontent: The Women's Movement in the Black Baptist Church, 1880-1920 (Cambridge, MA, 1993).

90. Iowa Bystander, 12/26/1930.

91. Iowa Bystander, 1/3/1963. 
quent. ${ }^{92}$ Whether it was the promulgation of uplift ideology, the turn to a national narrative of black history that rarely incorporated the local or regional, the demands of coping with the Depression and the war, the dispersal of celebration days across a larger calendar of events, or the possibility that the Iowa branches of the NAACP were not interested in trying to sustain a collective memory of slavery and emancipation, Emancipation Day receded from the commemorative calendar. ${ }^{93}$

As a result, Iowans lost not simply a holiday, but an important opportunity to sustain their connection to local and regional African American history, especially the region's ties to the national themes of slavery and emancipation. The history of slaveholding, of the hostile response to the arrival of former slaves from the war-torn South, the struggle for citizenship and civil rights, and the early history of black community- and institution-building no longer inspired the commemorative or celebratory spirit of white or black lowans. Since 1990, several black communities in Iowa have revived emancipation commemorations, in the form of Juneteenth Day celebrations; Cedar Rapids has seen the construction of the African American Historical Museum and Cultural Center of Iowa; and the first anthology of essays on African American history in Iowa has been published. As national debates over Civil War memory and the impact of slavery on contemporary race relations continue to evoke passionate arguments and shape public policy, perhaps Iowa's role in this national, regional, and local story will once again inspire public discourse, expressive culture, and a commitment to public history.

92. Wiggins, O Freedom, pays particular attention to the celebrations of the mid-twentieth century.

93. In recent years, Juneteenth has emerged as Iowa's most popular emancipation celebration date. Juneteenth celebrates June 19,1865, the day Union General George Granger belatedly informed Texas slaves of their freedom. Celebrations are found in a handful of lowa cities, and the state is one of seven to have declared it a state holiday, in accordance with a national movement to secure a federally recognized day of remembrance. See www.iowajuneteenth.org and www.juneteenth.com/3iowa_us.htm. 
Copyright of Annals of Iowa is the property of State of Iowa, by \& through the State Historical Society of Iowa and its content may not be copied or emailed to multiple sites or posted to a listserv without the copyright holder's express written permission. However, users may print, download, or email articles for individual use. 